\title{
Method on Conversion of Gasoline to Biogas Fueled Single Cylinder of Four Stroke Engine of Electric Generator
}

\author{
Tjokorda Gde Tirta Nindhia, I Wayan Surata, I Ketut Adi Atmika, Dewa Ngakan Ketut Putra Negara, \\ and Ari Wardana
}

\begin{abstract}
The Gasoline fueled single cylinder generator engine are well established and available in the market with reasonable price, in the other hand the biogas fueled engine for electric generator is not well established yet in the market. The biogas energy is easy to produce therefore the price for the biogas is very much cheaper than the gasoline. The purpose of this research is to find conversion method from gasoline to biogas fuelled of the single cylinder four stroke engine of electric generator. For this purpose the biogas should be upgraded to the level of zero impurities of hydrogen sulfide $\mathrm{H}_{2} \mathrm{~S}$, water $\left(\mathrm{H}_{2} \mathrm{O}\right)$ and reducing up to zero level of $\mathrm{CO}_{2}$ impurities. The carburetor of the gasoline engine was replaced and only component of the mixer of the fuel and air were used. The intake of the biogas fueled should be completed with valve that can be opened automatically by vacuum of the suction stroke of the engine and compression ration of the engine should be increased until reach 9:1 of compression ratio. With this conversion method, the engine of the electric generator used for this research is run well and possible to reach maximum capacity that can be achieved by using gasoline previously.
\end{abstract}

Index Terms-Conversion, gasoline, biogas, single cylinder, for stroke engine, electric generator.

\section{INTRODUCTION}

The progress of utilization biogas as a fuel for electric generator engine in developing country is found not as good as in the developed country. The difficulty in manufacturing the engine for biogas fueled engine still become a problem that yield in high price of the engine. Other problem is caused by the biogas qualities that vary among the region that make it difficult to upgrade in to the standard state for fueled the engine. As reported in previous publication [1] biogas composed of various gases such as methane (60-70\%), $\mathrm{CO}_{2}$ (30-40\%), nitrogen $(<1 \%)$, and $\mathrm{H}_{2} \mathrm{~S}(10-2000 \mathrm{ppm})$. This various composition make difficult for the user in setting of the engine, for example to run the electric generator.

Among all impurities in the biogas, the $\mathrm{CO}_{2}, \mathrm{H}_{2} \mathrm{~S}$ and water should be eliminated in order possible to be used as fuel of the engine. Some of the methods can be summarized as written bellow as a reference to be decided which method will be adopted and developed.

Manuscript received January 1, 2013; revised March 12, 2013. This work was supported by Ministry of National Education and Culture of The Republic of Indonesia under scheme of competitive research grant (skim penelitian hibah bersaing) for the year of 2013 granted through Udayana University, Jimbaran, Bali, Indonesia.

The authors are with the Department of Mechanical Engineering Udayana University, Jimbaran, Bali, 80361, Indonesia (e-mail: nindhia@yahoo.com, waysurat@yahoo.com,

devputranegara@yahoo.co.id,ko3pank@yahoo.co.id).
$\mathrm{H}_{2} \mathrm{~S}$ is removed in the first stage of biogas purification.

Two techniques are applied that are removal of $\mathrm{H}_{2} \mathrm{~S}$ during digestion and removal of $\mathrm{H}_{2} \mathrm{~S}$ after digestion [2].

For the method of removal $\mathrm{H}_{2} \mathrm{~S}$ during digestion, there are two types that are widely practiced namely by air-oxygen dosing to the biogas and addition of iron chloride into the digester. Air-oxygen dosing to the biogas system is based on the biological aerobic oxidation of $\mathrm{H}_{2} \mathrm{~S}$ to elemental sulfur by microorganisms [2]. Sulfide oxidizing microorganisms are autotrophic and use $\mathrm{CO}_{2}$ from the biogas to cover their carbon need. For the method of addition of iron chloride into the digester, the iron chloride can be penetrated directly into the digester or through the influent mixing tank. It reacts with the $\mathrm{H}_{2} \mathrm{~S}$ that present in the biogas to form particles of $\mathrm{FeS}$ [2].

There are many methods of removal of $\mathrm{H}_{2} \mathrm{~S}$ after digestion, adsorption using iron oxide or hydroxide for example. Hydrogen sulfide reacts easily with iron oxide or iron hydroxide and forms iron sulfide. The other technique is absorption with liquids that can be either physical or chemical. Chemical absorption involves dissolving the component followed by a chemical reaction of the trace component and the solvent whereas physical absorption involves dissolving the trace component in the solvent, Physical absorption removes $\mathrm{H}_{2} \mathrm{~S}$ by absorption in water or an organic solvent. The most common solvent is water scrubbing, although the growths of microorganisms in the packing occur. Single pass absorption and regenerative absorption are two types of water absorption processes that commonly used for the upgrading of biogas. The disadvantage is a high consumption of water is needed, there for regeneration process should be promoted [2].

$\mathrm{H}_{2} \mathrm{~S}$ can be separated from the gas by leading the gas through a semi permeable membrane (membrane separation technique). $\mathrm{H}_{2} \mathrm{~S}$ able pass through the membrane but not $\mathrm{CH}_{4}$. The important component is a micro porous hydrophobic membrane that able to separating the gas from liquid phase. The molecules from the gas stream, flowing in one direction, diffuse through the membrane and will be absorbed on the other side by the liquid, flowing in counter current. For this purpose $\mathrm{NaOH}$ can be used as the absorbent liquid [2].

The method that is similar to the technique where air- $\mathrm{O}_{2}$ was added to the digestion is biological filter. It is use specific bacteria that are able to oxidize $\mathrm{H}_{2} \mathrm{~S}$. Before entering the filter bed, air is added to the biogas. The $\mathrm{H}_{2} \mathrm{~S}$ is absorbed in the liquid phase, made up from gas condensate and liquid from effluent slurry separation. After absorption, $\mathrm{H}_{2} \mathrm{~S}$ is oxidized by the bacteria, growing on the filter bed. The $\mathrm{H}_{2} \mathrm{~S}$ is biologically converted to sulfur. Sulfur is retained in the 
liquid of the filter. Other benefit of Biological filtration is applied in several installations for removing odors it is cheaper than chemical cleaning and possible to remove ammonia from the biogas. It is reported also $\mathrm{H}_{2} \mathrm{~S}$ can also be removed by using activated carbon [2].

As mentioned previously beside $\mathrm{H}_{2} \mathrm{~S}$, the $\mathrm{CO}_{2}$ gas should also eliminate for the purpose of upgrading biogas for fueled the spark ignition engine. Several techniques are introduced here that was obtained from literature study in order proper decision could be obtained.

Physical and chemical $\mathrm{CO}_{2}$ absorption. The $\mathrm{CO}_{2}$ and $\mathrm{CH}_{4}$ are separated by using absorbent. Water can be used as physical absorbent. $\mathrm{CO}_{2}$ is separated from the biogas by reacting with water at high pressure. Biogas is entered from the bottom of vertical column. Water is fed at the top of the column to achieve a gas-liquid counter flow [2].

Pressure swing adsorption (PSA) or vacuum swing adsorption (VSA). PSA and VSA use a column filled with a molecular sieve (silica gel, alumina, activated carbon or zeolite), for adsorption of the gases $\mathrm{CO}_{2}$ and letting $\mathrm{CH}_{4}$ pass through. The molecules are adsorbed loosely in the cavities of the molecular sieve [2]

Membrane separation is based on the selective permeability property of membranes. Two basic systems exist: gas-gas separation with a gas phase at both sides of the membrane and gas-liquid absorption separation with a liquid absorbing the diffused molecules. Multiple stages may be required due to imperfect separation that would increase the methane loss. This problem can be overcome by recirculation [2].

Cryogenic separation. Since $\mathrm{CH}_{4}, \mathrm{CO}_{2}$ and other impurities liquefy in different temperature or pressure, it is possible to obtain methane by cooling and compressing the biogas. The liquid $\mathrm{CO}_{2}$ is also a solvent separating remaining impurities from the gas [2].

Biological methane enrichment. Specific methanogens using only $\mathrm{CO}_{2}$ as a carbon source and $\mathrm{H}_{2}$ as an energy source. The selection between mesophilic and thermophilic operation temperatures is typically based on whether the completion of reaction or the rate of reaction is of primary concern. Thermophilic methanogens exhibit rapid methanogenesis, while mesophilic bacteria give more complete conversion of the available $\mathrm{CO}_{2}$ [2] .

Removal of $\mathrm{CO}_{2}$ and $\mathrm{H}_{2} \mathrm{~S}$ from biogas by aqueous solutions in a packed column can be done by using sodium hydroxide $(\mathrm{NaOH})$, calcium hydroxide $\left(\mathrm{Ca}(\mathrm{OH})_{2}\right)$ and mono-ethanolamine (MEA) as liquid solvent. Liquid solvents were circulated through the column, contacting the biogas in countercurrent flow. Test results indicated similar absorption patterns between the chemical solvents used. Chemical absorption by solvents in a packed column was an effective technique for removing $\mathrm{CO}_{2}$ over a short operation time, but their absorption capability declined rapidly with time. $\mathrm{Ca}(\mathrm{OH})_{2}$ appeared to become saturated more rapidly than the other solvents[3].

Untreated or raw biogas is usually saturated with water and the absolute water quantity depends on the temperature. The lower the temperature, the lower the water content in the raw biogas. The removal methods for water are generally based on physical separation of condensed water or chemical drying [2].

Physical drying methods. The simplest way of removing excess water vapor is through refrigeration. To achieve lower dew points the gas has to be compressed before cooling and then later expanded to the desired pressure. The lower the dew point, the higher pressure is needed to be applied. The condensed water droplets are entrapped and removed. The physical drying methods prevent water contact with downstream equipment like compressors, pipes, activated carbon beds and other parts of the process. In this way, corrosion is prevented [2].

Chemical drying methods. These techniques are usually applied at elevated pressures. At atmospheric pressure only a small amount of water is removed by the absorption and adsorption techniques. Adsorption using alumina or zeolites molecular sieves is the most common technique [2].

Beside its difficulty for fueled the engine, biogas has advantages as alternative energy since easy to produce even from municipal waste [4]. This make that the effort to use biogas to fueled the engine should be promoted and supported as what happened in the developed country. Recently the biogas is possible to use for driven air conditioning system [5], and more even at the sub tropical region, the used of biogas was proven well for combined heat and powered (CHP) for establishing electricity and heating during winter [6]. Further more The results show that implementation of a biogas-based CHP plant result in an electricity power production, Reduced system costs provide a profitability, $\mathrm{CO}_{2}$ emission reductions [7]. The benefit of biogas instead for providing electricity demand is also possible for heat production, reducing the odor, reducing greenhouse effect, and more even can producing fertilizer for agriculture. It was calculated that from about $7595 \mathrm{~m}^{3} /$ day methane gas could be obtained about 77.4 MWh of electricity [8]. This conclusion can be use to ensure the effort of providing electricity from biogas should be continued and encouraged [8].

There is an improvement in thermal efficiency and power output of a biogas fuelled spark ignition engine with very lean mixtures and a hydrogen concentration of $15 \%$ [9]. But utilization and application and implementation of this idea is far from easy especially in the developing word particularly in providing hydrogen for this purpose.

The engine fueled with mixture of biogas and city gas was already developed [10] and reported run well, but the engine performance during using single fueled biogas was not reported yet in this report. The used of city gas should be questioned because will need more cost to provide especially for the farm in rural area.

The purpose of this research is to develop method for conversion from gasoline to biogas fueled small engine to run the electric generator to reach the performance of gasoline fueled engine to generate electricity which is reliably to be implemented in the developing world.. The small fueled gasoline engine was from the specification that easily to be found and widely available in the market of developing country. 


\section{EXPERIMENTAL}

The selected engine for this purpose was 4-stroke gasoline engine, air-cooled, and inclined single cylinder. The displacement is $196 \mathrm{cc}$, the compression ration of the engine was increased from 8.5:1 to reach around 9:1. The ignition system was non contact transistor ignition (TCI).

The biogas obtained from digester was desulfurized by using annealed and compacted steel waste chips from the waste of turning process in. The detail of processing can be access in our previous report [11]. The annealed and compacted billet used for this research is presented in Fig. 1, and detail schematic of conversion method from gasoline to biogas fueled electric generator engine can be seen in the Fig. 2 .

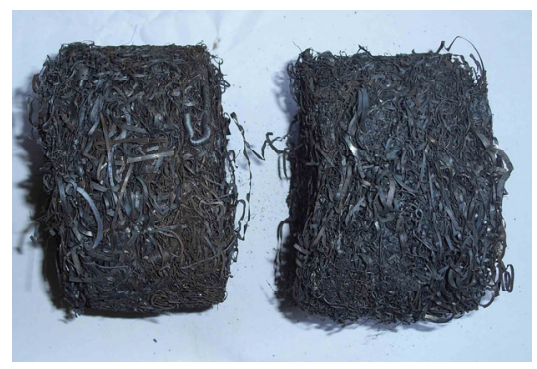

Fig. 1. Annealed and compacted billet of steel waste chips as desulfurizer

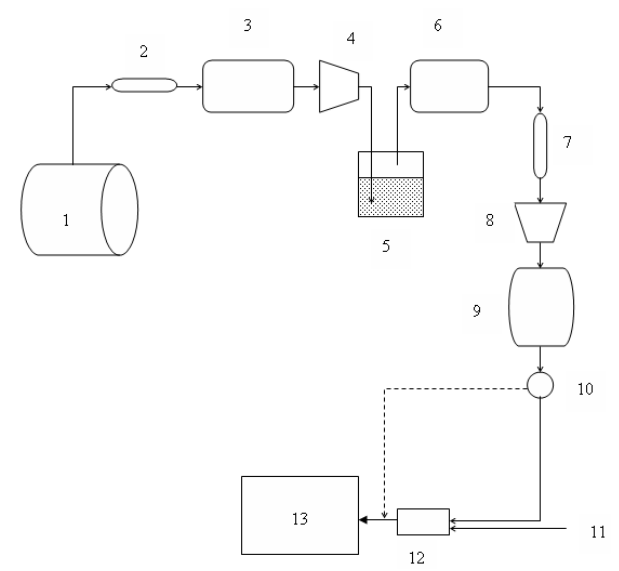

Fig. 2. Schematic of conversion method from gasoline to biogas fueled electric generator engine. 1. Digester, 2. Desulfurizer, 3. First bag of gas holder, 4. Low pressure compressor, 5. $\mathrm{CO}_{2}$ elimination, 6. Second bag of gas holder,7. Dehumidifier, 8. High pressure of compressor, 9. Biogas container, 10. vacuum powered valve, 11. air intake, 12. Biogas and Air mixer, 13. Engine

To ensure that the biogas is free from $\mathrm{H}_{2} \mathrm{~S}$ impurities, the $\mathrm{H}_{2} \mathrm{~S}$ contents in the biogas was checked before and after passing the desulfurizer. If the $\mathrm{H}_{2} \mathrm{~S}$ still found in the biogas the addition of billet of annealed and compacted desulfurizer should be done. The biogas with free impurities of $\mathrm{H}_{2} \mathrm{~S}$ was flowed to entering the first bag of gas holder. The low pressure of compressor was used to pump the biogas from the first bag of gas holder to entering the component of $\mathrm{CO}_{2}$ removal which was contain with solution of $10 \% \mathrm{NaOH}$ in water $\left(\mathrm{H}_{2} \mathrm{O}\right)$. The biogas was collected afterward in the second bag of gas holder and after that it was ready to entering the process of dehumidification to ensure that the biogas free from water content. From this point the biogas was ready to be compressed in to the biogas container until reach about $4 \mathrm{MPax} 10^{-1}$. The valve which will open by vacuum mechanism of the intake manifold was installed to arrange the flow of the biogas. With this valve the gas will flow in to the intake of the manifold and will stop if the engine not running. The biogas then was continued to flow in to the mixer part.

This mixer component is part of the carburetor in the gasoline fueled engine but the carburetion cup was replaced and only mixer part was remain. Together with biogas, the air was flowed in to the mixer, and directed in to the intake valve of the combustion chamber. It should be noted here that during starting the engine, the flow rate of the biogas was let maximum and reduce the rate gradually until the engine start running, and the rate of air flow in to the mixer was adjusted until the engine run stable.

\section{RES ULT AND DisCUSSION}

By using desulfurizer the biogas can be upgraded to zero content of $\mathrm{H}_{2} \mathrm{~S}$ impurities that lead to avoid increasing acidity [11] of the lubricant therefore the corrosion in the combustion chamber can be avoided. Previously the existence of $\mathrm{H}_{2} \mathrm{~S}$ in the biogas was overcome by increasing frequency of engine oil change which is will increase the operating cost [12]. Other urgent thing that make $\mathrm{H}_{2} \mathrm{~S}$ should be eliminated due to $\mathrm{H}_{2} \mathrm{~S}$ is a toxic gas [2]. In this report the used of annealed and compacted billet of steel waste chips was found successful in elimination of $\mathrm{H}_{2} \mathrm{~S}$ impurity. The steel which is main content is iron $(\mathrm{Fe})$ transformed to both iron oxide $\left(\mathrm{Fe}_{2} \mathrm{O}_{3}\right)$ and iron hydroxide $\left(\mathrm{Fe}_{2}(\mathrm{OH})_{3}\right)$ during annealing process. Iron oxide and iron hydroxide was recognized easy to react with $\mathrm{H}_{2} \mathrm{~S}$ and form iron sulfide as reaction in Equation 1 and 2 bellow [2]:

$$
\begin{gathered}
\mathrm{Fe}_{2} \mathrm{O}_{3}+3 \mathrm{H}_{2} \mathrm{~S} \rightarrow \mathrm{Fe}_{2} \mathrm{~S}_{3}+3 \mathrm{H}_{2} \mathrm{O} \\
2 \mathrm{Fe}(\mathrm{OH})_{3}+3 \mathrm{H}_{2} \mathrm{~S} \rightarrow \mathrm{Fe}_{2} \mathrm{~S}_{3}+6 \mathrm{H}_{2} \mathrm{O}
\end{gathered}
$$

It is should be noted that the reaction in Eq. 1 and 2 are very sensitive to water [2] therefore drying process of this type of desulfurizer during maintenance is obligatory. The process of desulfurization in this research was conducted at early process that is after the biogas come out from the digester. The main reason is to protect the gas pump, compressor and storage tank from corrosion since it is known $\mathrm{H}_{2} \mathrm{~S}$ is very corrosive to metal [2] especially steel.

The elimination of the $\mathrm{CO}_{2}$ impurities by flowing the biogas in to the solution of $10 \% \mathrm{NaOH}$ in water $\left(\mathrm{H}_{2} \mathrm{O}\right)$ was found easier that the method proposed by by Chien et al. [13] and also Tippayawong and Thanompongchart, [3]. By reducing the water content in the biogas up to zero level affect in easy starting of the engine.

The use of the bag gas holder of the biogas was useful during compressing of the biogas in to the gas container because this is make easy to be observed whether biogas available or not during compression. The bag gas holder can be made from plastic bag and this is actually from the balloon of tube type of digester [14]. Other type of digester such as fixed dome digester [14] was found not suitable during compression gas because we can not observe the availability of the biogas. Mean while floating cover digester [14] was found increasing water content in the biogas during suction for the purpose of compression in to the biogas container.

The silica that was used for dehumidifier in this research 
was found working well to eliminate the water content in the biogas. This process was known as drying process by adsorption dryer [2]. The silica grain provided in this research was adsorbing the water and the grain joint together in the form of solid tubular. The solid silica can be crashed to become grain and heating for regeneration.

The compression ration in this research was increased step by step from 8.5:1 until yield condition in which the engine was easy to start running and run stable. The final compression ration was 9:1 which reached minimum compression ratio for the biogas fueled spark ignition engine [15].

The conversion methods that is developed in this research was successful to run the electric generator engine that previously fueled by gasoline to be converted by using biogas The engine run stable and can produce electricity. The maximum RPM (revolution per minutes) that can be obtained by using biogas was found can reach the maximum RPM obtained by using gasoline fuel which is around 3600 RPM.

\section{CONCLUSION}

The conversion from gasoline to biogas fueled engine can be achieved by desulfurizing of the biogas at the firs step continued with elimination of $\mathrm{CO}_{2}$ impurity and then dehumidification and put the gas in to the bag of gas holder. The biogas afterward should be compressed in to the gas container for easy mixing process with oxygen from the air. The carburetion component was replaced and only mixer part of the fuel is used and before entering the mixer, the valve controlled by vacuum of suction stroke of the piston is installed to control the flow of the biogas during on-of process of the engine. During starting process, the biogas is let to flow in maximum flow rate and reduce the rate until engine start running. The process is followed by adjusting the air flow in to the mixer until the engine run stable.

\section{ACKNOWLEDGEMENT}

The authors wish to thank the Ministry of National Education and Culture of The republic of Indonesia for financial support under scheme of competitive research grant (skim penelitian hibah bersaing) for the year of 2013 granted through Udayana University, Jimbaran, Bali, Indonesia.

\section{REFERENCES}

[1] F. Osorio and J. C. Torres, "Biogas purification from anaerobic digestion in a wastewater treatment plant for biofuel production," Renewable Energy, vol. 34, pp. 2164-2171, March 2009.

[2] E. Ryckebosch, M. Drouillon, and H. Vervaeren, "Techniques for Transformation of Biogas To Biomethane," Biomass and Bioenergy, vol. 35, pp. 1633-1645, March 2011.

[3] N. Tippayawong and P. Thanompongchart, "Biogas Quality Upgrade by Simultaneous Removal of $\mathrm{CO}_{2}$ and $\mathrm{H}_{2} \mathrm{~S}$ in A Packed Column Reactor," Energy, vol. 35, pp. 4531-4535, May 2010.

[4] N. Kuwahara, M. D. Bern, and S. V. Bajay, "Energy Supply from Municipal Waste: The Potensial of Biogas-fueled Buses in Brazil," Renewable Energy, vol. 16, pp. 1000-1003, January 1999.

[5] D. Damrongsk and N. Tippayawing, "Experimental investigation of an automotive air-conditioning system driven by a small biogas engine,' Applied Thermal Engineering, vol. 30, pp. 400-405, September 2010.

[6] R. P. J. M. Raven and K. H. Gregersen, "Biogas plants in Denmark: successes and setbacks," Renewable and Sustainable Energy Reviews, vol. 11, pp. 116-132, December 2007
[7] S. Amiri, D. Henning, and B. G. Karlsson, "Simulation and introduction of a CHP plant in a Swedish biogas system," Renewable Energy, vol. 49, pp. 242-249, January 2013.

[8] P. Sefeedpari, S. Rafiee, and A. Akram, "Providing Electricity Requirements by Biogas Production and Its Environmental Benefit in Sample Dairy Farms of Iran," International Journal of Renewable Energy Research, vol. 2, no. 3, pp. 384-387, May 2012.

[9] E. Porpatham, A. Ramesh, and B. Nagalingam, "Effect of hydrogen addition on the performance of a biogas fuelled spark ignition engine," International Journal of Hydrogen Energy, vol. 32, pp. 2057-2065, October 2007

[10] Y. Yamasaki, M. Kanno, Y. Suzuki, and S. Kaneko, "Development of an engine control system using city gas and biogas fuel mixture," vol. 101, pp. 465-474, January 2013

[11] T. G. T. Nindhia, "Removal of Hydrogen Sulfide $\left(\mathrm{H}_{2} \mathrm{~S}\right)$ contaminant in Biogas by Utilizing Solid Waste Steel Chips from The Process of Turning," in Proc. Twenty-seventh International Conference on Solid Waste Technology and Management, Philadelphia, PA U.S.A., 2012, March 11-14. pp 259-264

[12] J. Huanga, and R. J. Crookesb, "Assessment of simulated biogas as a fuel for the spark ignition engine," Fuel, vol. 77, no. 15, pp. 1793-1801, June 1998

[13] Y. K. Chien, Y. C. Sheng, T. H. Tzu, D. Le, K. H. Ling, and S.L. Chih, "Ability of A Mutant Strain of The Microalga Chlorella sp. To Capture Carbon Dioxide for Biogas Upgrading," Applied Energy, vol. 93, pp. 176-183, January 2012.

[14] T. Bond and M. R. Templeton, "History and future of domestic biogas plants in the developing world," Energy for Sustainable Development, vol. 15, pp. 347-354, October 2011.

[15] E. Porpatham, A. Ramesh, and B. Nagalingam, "Effect of compression ratio on the performance and combustion of a biogas fuelled spark ignition engine," Fuel, vol. 95, pp. 247-256, November 2011.

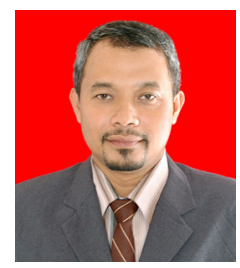

Tjokorda Gde Tirta Nindhia Was born in Denpasar, Bali, Indonesia on January $16^{\text {th }}$, 1972. Received Doctor Degree in Mechanical Engineering from Gadjah Mada University (UGM) Yogyakarta, Indonesia on August 2003, with major field of study was Material Engineering.

He participated in various international research collaboration such as with Muroran Institute of Technology Japan (2004), Toyohashi University of Technology Japan (2006), Leoben Mining University Austria (2008-2009), Technical University of Vienna Austria (2010) and Recently with Institute Chemical technology of Prague Czech Republic (2012-now). His current job is as Full Professor in the field of Material Engineering at Department of Mechanical Engineering, Engineering Faculty, Udayana University, Jimbaran, Bali, Indonesia. His research interest covering subjects such as, biomaterial, waste recycle, failure analyses, ceramic, metallurgy, composite, renewable energy, and environmental friendly manufacturing.

Prof. Nindhia is a member of JICA Alumni, ASEA-UNINET alumni, and also member of association of Indonesian Nanotechnology. Prof Nindhia received best researcher award in 1997 from Udayana University the place where he is working and again in 2012 received both Best researcher award from Engineering Faculty of Udayana University and from Udayana University.

I Wayan Surata was born in Nusa Penida, Bali, Indonesia on July 5, 1958 Received Doctor Degree in the field of Ergonomic from Udayana University in 2011. His research interest very much related in process of manufacture. His Current job is researcher and lecturer at Department of Mechanical Engineering, Engineering Faculty, Udayana University, Jimbaran, Bali, Indonesia.

I Ketut Adi Atmika was born in Negara, Bali, Indonesia on May 18, 1969. Received Master degree in mechanical engineering From Institute Technology of Sepuluh November, Surabaya, Indonesia. His Current job is researcher and lecturer at Department of Mechanical Engineering, Engineering Faculty, Udayana University, Jimbaran, Bali, Indonesia.

Dewa Ngakan Ketut Putra Negara was born in Payangan, Bali, Indonesia on June 13, 1971. Received M.Sc from University of Bradford, UK in 2001 in Manufacturing Systems Engineering and Management. His Current job is researcher and lecturer at Department of Mechanical Engineering, Engineering Faculty, Udayana University, Jimbaran, Bali, Indonesia.

Ari Wardana was born in Kupang, Indonesia on November 1, 1985. He is in the final stage in finishing his undergraduate course at Department of Mechanical Engineering, Engineering Faculty, Udayana University, Jimbaran, Bali, Indonesia. 